\section{Ambient air quality and indexing with reference to suspended particulate matter and gaseous pollutants around a cement plant in OCL India Limited, Rajgangpur, Odisha, India}

\author{
Ambikesh Kumar Mishra ${ }^{1, *}$, \\ Manish Kumar Jain ${ }^{2}$ and Suvendu Kumar Dash ${ }^{3}$ \\ ${ }^{1}$ Paradeep Phosphates Limited, Odisha 770 017, India \\ ${ }^{2}$ Department of Environmental Science and Engineering, \\ Indian Institute of Technology, Dhanbad 826 004, India \\ ${ }^{3}$ Department of Environmental Engineering, Institute of Technical \\ Education and Research, Siksha 'O' Anusandhan (Deemed to be \\ University), Bhubaneswar 751030 , India
}

Cement industry is a potential anthropogenic source of air pollution. Emissions from cement plants are one of the major sources of global warming. The dusts produced were very hazardous, which affect the surrounding environment. The present study was undertaken to analyse the air quality around a cement plant (OCL India Ltd, Odisha) within $2 \mathrm{~km}$ radius for a period of 8 months stating from October 2016 to May 2017 at four different locations with meteorological parameters. The observed values of air pollutants are found within the prescribed standards according to Central Pollution Control Board (CPCB), New Delhi. This is possible because of the initiative taken by industries by installing advanced air trapping devices. The results of this study have been presented in the form of air quality index, where we found the study area in moderate $\left(\mathrm{PM}_{10}\right)$ and good category $\left(\mathrm{SO}_{2}\right.$ and NO $)_{x}$.

Keywords: Ambient air quality, cement plant, gaseous pollutants, suspended particulate matter.

A progressive degradation of air quality has been observed in India and other developing countries due to urbanization, industrialization, increase in the number of motor vehicles, lack of awareness among people, use of fuels with poor environmental performance and ineffective environmental regulations ${ }^{1-3}$. Cement industry is one of the most basic industries involved in the development of a country. India is the second largest producer of cement after China, due to availability of limestone belt. Cement is the most widely used building material throughout the world. The size, concentration and duration of exposure of pollutants have an impact on the nearby areas ${ }^{4-6}$. Assessment of ambient air quality and its impact on the nearby environment has been carried out ${ }^{7-11}$.

The cement processing units are a potential anthropogenic source of air pollution, which contribute dust in the form of $\mathrm{PM}_{10}, \mathrm{PM}_{2.5}, \mathrm{NO}_{x}, \mathrm{SO}_{x}$ and $\mathrm{CO}$ in metropolitan

*For correspondence. (e-mail: ambikesh2010@gmail.com) areas, emitted from stock piles, quarrying, raw materials transportation and operation of kilns ${ }^{12}$. Gases like $\mathrm{CO}_{2}$, $\mathrm{SO}_{2}$ and $\mathrm{NO}_{2}$ are generated as a by-product from power plants ${ }^{13,14}$. In addition, $\mathrm{SO}_{2}$ is produced from oxidation of volatile sulphur present in limestone used as raw materi$\mathrm{al}^{15}$. Also, it contributes about $5 \%$ of the global CO. In Egypt, it has been reported that $1 \mathrm{~kg}$ of cement manufactured generates about $0.07 \mathrm{~kg}$ of dust in the atmosphere ${ }^{16}$. The importance of mixing height was studied and it was found to have a major influence on the magnitude of ground-level concentration ${ }^{17-19}$

Several studies have been carried out on the status of ambient air quality ${ }^{20-24}$. Deterioration of ambient air quality and its impact on vegetation and human health in and around different mining and industrial areas have been reported $^{25-31}$. Studies related to short-term health impacts have also been conducted ${ }^{32,33}$.

About $2 \%$ of global energy is consumed by the cement industry and around $5 \%$ of $\mathrm{CO}_{2}$ emitted to the atmosphere is due to cement production ${ }^{34,35}$. Due to high $\mathrm{PM}_{10}$ levels in the major cities, there is an increase in morbidity and mortality rates ${ }^{36-38}$.

The study was conducted around a cement plant - OCL India Ltd, Odisha - at four locations (N, S, E and W) within $2 \mathrm{~km}$ radius. Table 1 and Figure 1 provide more details about these locations.

The study was carried out over 8 months, i.e. from October 2016 to May 2017, and measurements were taken on monthly basis with $24 \mathrm{~h}$ sampling.

Meteorological data were taken from the Weather Monitoring Station (WM 271) installed in the Cement Division of OCL India Ltd (Figure 2). Data on daily maximum, minimum and average temperature, relative humidity and rainfall were considered for the study.

Parameters such as $\mathrm{PM}_{10}, \mathrm{PM}_{2.5}, \mathrm{SO}_{x}, \mathrm{NO}_{x}$ were analysed according to the standard guidelines stipulated by the Central Pollution Control Board (CPCB), Government of India ${ }^{39,40}$. Table 2 provides details of parameters with analysis method used.

The results of the study show the 24 hourly mean concentration of different air pollutants. It is evident that most of the readings are within permissible units. Values within the tolerance level signify a positive approach towards sustainable development. From the monitored values, it has been observed that most of the time the readings are within permissible standards given in Table 3.

Table 1. Details of study area

\begin{tabular}{lclll}
\hline Station & Station code & Direction & Latitude & Longitude \\
\hline Ranibandh & ST-1 & North & 22.207525 & 84.589013 \\
OCL market & ST-2 & South & 22.196541 & 84.584976 \\
IT colony & ST-3 & East & 22.200781 & 84.596258 \\
Liploi & ST-4 & West & 22.198000 & 84.574931 \\
\hline
\end{tabular}




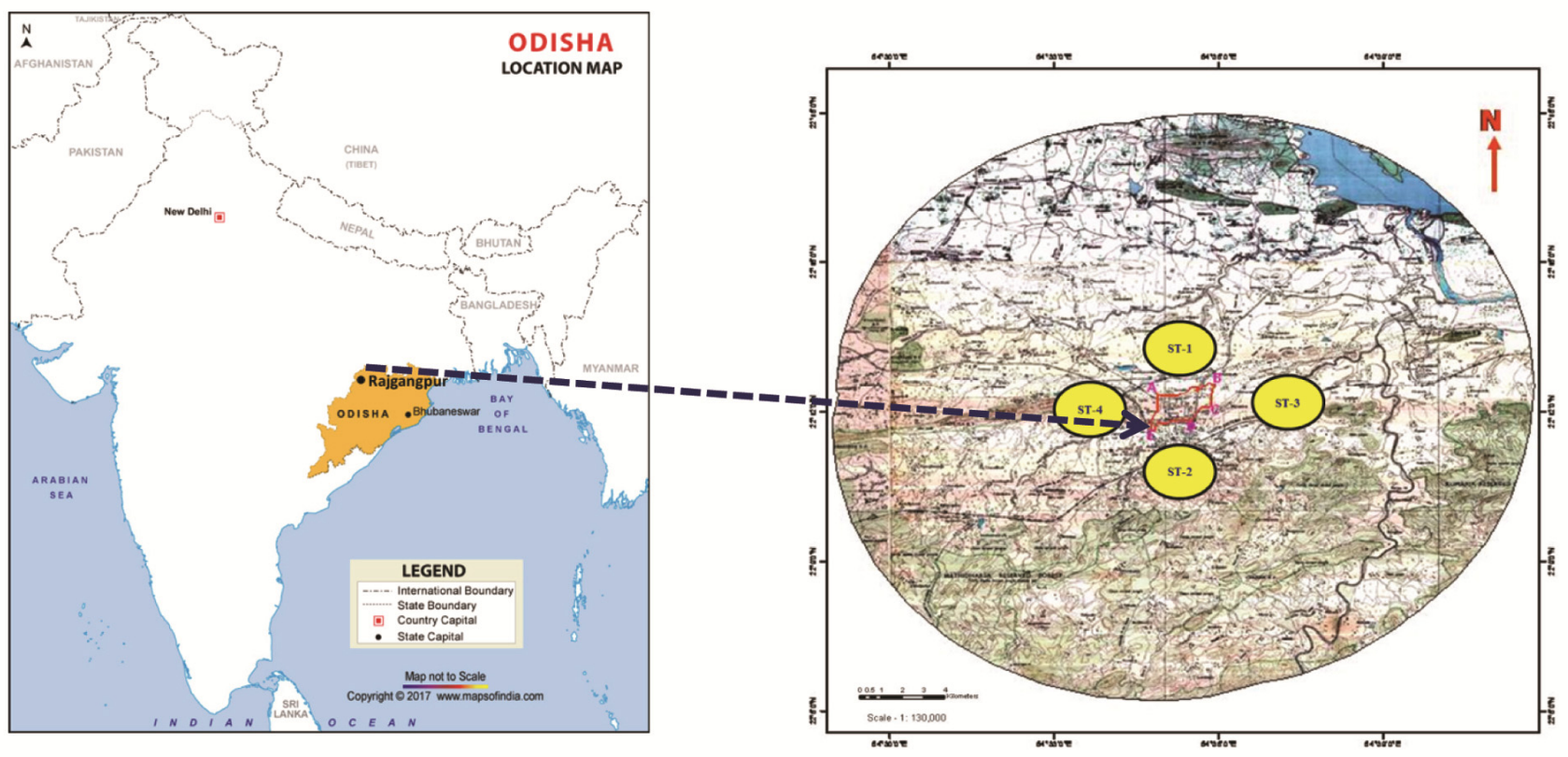

Figure 1. Location map with details of stations.
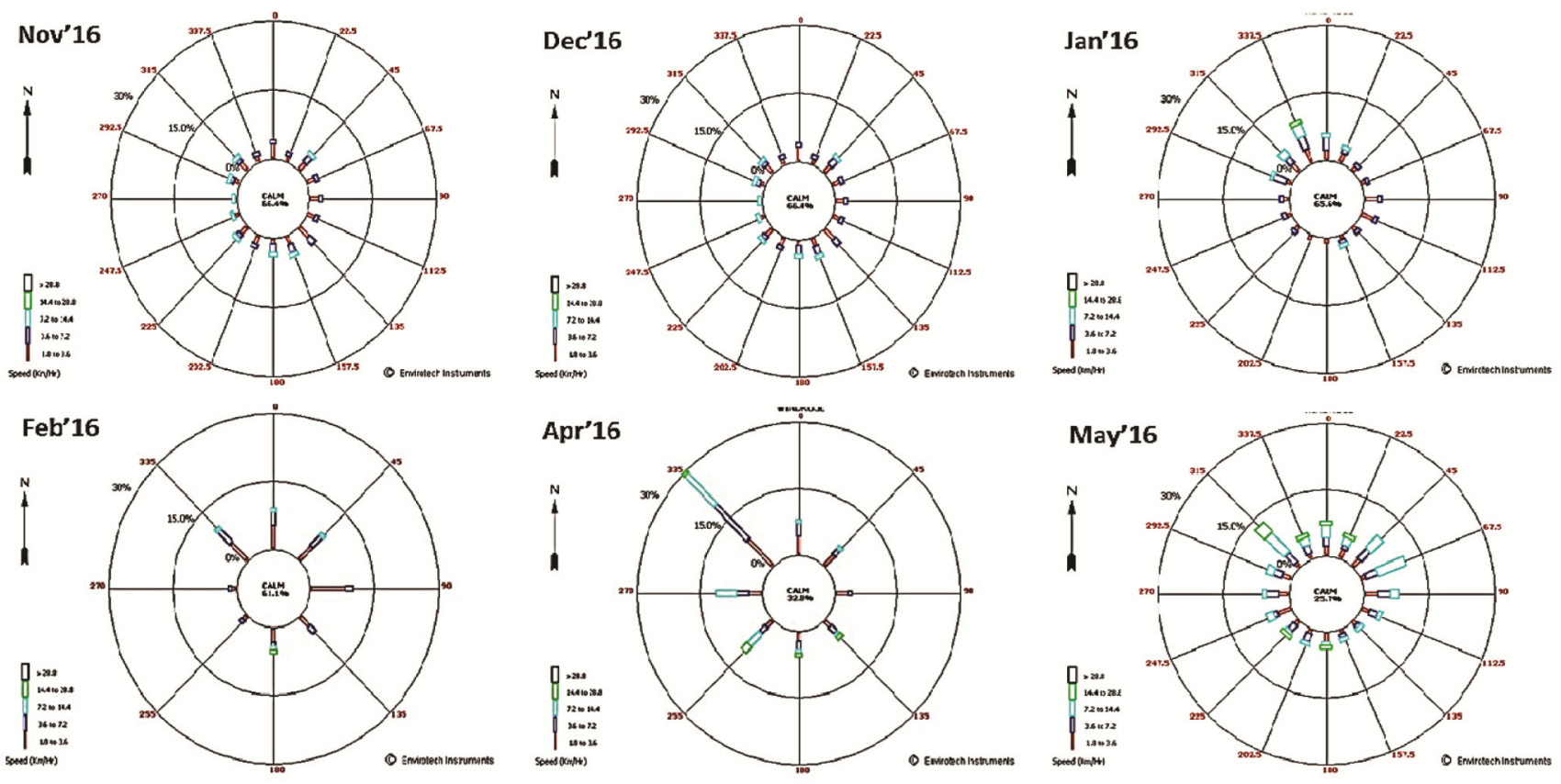

Figure 2. Month-wise wind rose diagram.

Table 2. Details of air quality monitoring equipment and methods used for analysis

\begin{tabular}{|c|c|c|c|c|}
\hline Instrument Ser. no. & Model & Make/Supplier & Parameters & Methods according to CPCB \\
\hline 1536-DTG-2009 & APM 460BL & ENVIROTECH & SPM & $\begin{array}{l}\text { Gravimetric method with respirable dust samples } \\
\text { (average flow rate not less than } 1.1 \mathrm{~m}^{3} / \mathrm{min} \text { ) }\end{array}$ \\
\hline 1537-DTG-2009 & APM 460BL & ENVIROTECH & RPM & Same as the above \\
\hline 1338-DTG-2009 & APM 460BL & ENVIROTECH & $\mathrm{SO}_{x}$ & Improved West and Gaeke method \\
\hline 1339-DTG-2009 & APM 460BL & ENVIROTECH & $\mathrm{NO}_{x}$ & Jacob and Hechheiser method \\
\hline 39-DTA-2009 & WM-271 & ENVIROTECH & Meteorological data & \\
\hline
\end{tabular}


RESEARCH COMMUNICATIONS

Table 3. Values of ambient air quality results for four stations $\left(\mu \mathrm{g} / \mathrm{m}^{3}\right)$

\begin{tabular}{|c|c|c|c|c|c|c|c|c|}
\hline Month and year & October 2016 & November 2016 & December 2016 & January 2017 & February 2017 & March 2017 & April 2017 & May 2017 \\
\hline \multicolumn{9}{|l|}{ ST-1 } \\
\hline $\mathrm{PM}_{10}$ & 114.3 & 108 & 110.5 & 122.5 & 114.3 & 120.6 & 101.6 & 116.2 \\
\hline $\mathrm{PM}_{2.5}$ & 38.68 & 52.74 & 41.15 & 40.98 & 38.68 & 54.87 & 37.72 & 48.01 \\
\hline $\mathrm{SO}_{2}$ & 5.20 & 5.00 & 5.30 & 5.10 & 4.80 & 5.30 & 4.20 & 5.30 \\
\hline $\mathrm{NO}_{x}$ & 41.1 & 48.8 & 54.8 & 46.4 & 53 & 31 & 42.9 & 28.6 \\
\hline $\mathrm{PM}_{10}$ & 94.7 & 88.4 & 98.5 & 93.4 & 94.7 & 94.7 & 85.9 & 99.7 \\
\hline $\mathrm{PM}_{2.5}$ & 24.61 & 21.10 & 30.86 & 34.29 & 27.43 & 34.29 & 34.29 & 37.72 \\
\hline $\mathrm{SO}_{2}$ & 4.6 & 4.7 & 3.8 & 4.1 & 4.4 & 3.9 & 4.3 & 4.6 \\
\hline $\mathrm{NO}_{x}$ & 20.2 & 21.4 & 31 & 22.6 & 29.2 & 15.5 & 13.1 & 17.9 \\
\hline \multicolumn{9}{|l|}{ ST-3 } \\
\hline $\mathrm{PM}_{10}$ & 62.3 & 69.4 & 63.3 & 62.5 & 62.3 & 70.1 & 75.9 & 70.1 \\
\hline $\mathrm{NO}_{x}$ & 17.3 & 31.5 & 32.7 & 30.4 & 23.2 & 37.5 & 20.8 & 40.5 \\
\hline \multicolumn{9}{|l|}{ ST-4 } \\
\hline $\mathrm{PM}_{10}$ & 106.7 & 108.6 & 106.1 & 101 & 100.4 & 96 & 99.7 & 106.7 \\
\hline $\mathrm{PM}_{2.5}$ & 49.23 & 31.65 & 37.72 & 30.86 & 44.00 & 43.20 & 41.15 & 34.29 \\
\hline $\mathrm{SO}_{2}$ & 3.90 & 3.40 & 3.20 & 4.10 & 2.80 & 3.80 & 2.10 & 2.60 \\
\hline $\mathrm{NO}_{x}$ & 22.6 & 14.9 & 26.8 & 30.4 & 34.5 & 20.8 & 32.7 & 36.3 \\
\hline
\end{tabular}

Table 4. Station-wise Ip values of different parameters

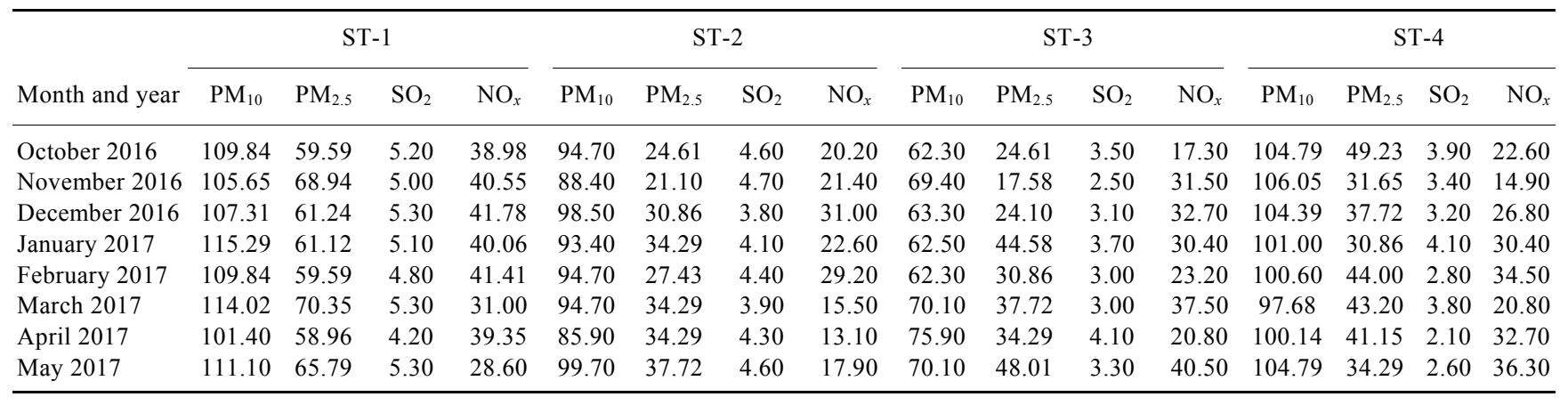

Table 4 shows the Ip (pollutant concentration) values based upon the ambient air quality monitored and calculated according to the CPCB 2014 guidelines. The maximum Ip values are considered as the air quality index (AQI) of an area according to the formula (Table 5).

$$
I_{p}=\left[\left\{\left(I_{H I}-I_{L O}\right) /\left(B_{H I}-B_{L O}\right)\right\} *\left(C_{p}-B_{L O}\right)\right]+I_{L O},
$$

$I_{p}$ is the sub-index, $B_{H I}$ the breakpoint concentration greater or equal to the given concentration, $B_{L O}$ the breakpoint concentration smaller or equal to the given concentration, $I_{H I}$ the $\mathrm{AQI}$ value corresponding to $\mathrm{B}_{\mathrm{HI}}, I_{L O}$ the $\mathrm{AQI}$ value corresponding to $\mathrm{B}_{\mathrm{LO}}, C_{p}$ is the pollutant concentration.

Finally

$$
\mathrm{AQI}=\max \left(I_{p}\right)
$$

where $p=1,2, \ldots, n$ denotes $n$ pollutants.
The observed values show that the pollution load and emission levels are well within acceptable limits. The cement plant under study, does not have any adverse effect upon the environment with reference to air pollution. The maximum AQI values were observed in ST-1 during March 2017, i.e. 114.02 followed by 106.05 in ST-4 during November 2016. Figure 3 shows the monthwise as well as station-wise variation of AQI.

From a comparison of standard permissible values and observed readings, it can be concluded that the emissions to the atmosphere are within acceptable limits. It is evident that the cement plant under study has adopted adequate technical pollution control measures. These observations have been made for a short duration only. However, the sampling signifies the overall performance of the technological control measures taken by the cement plant.

From the study it can be concluded that the mean concentration values are found to be beyond the CPCB 


\section{RESEARCH COMMUNICATIONS}

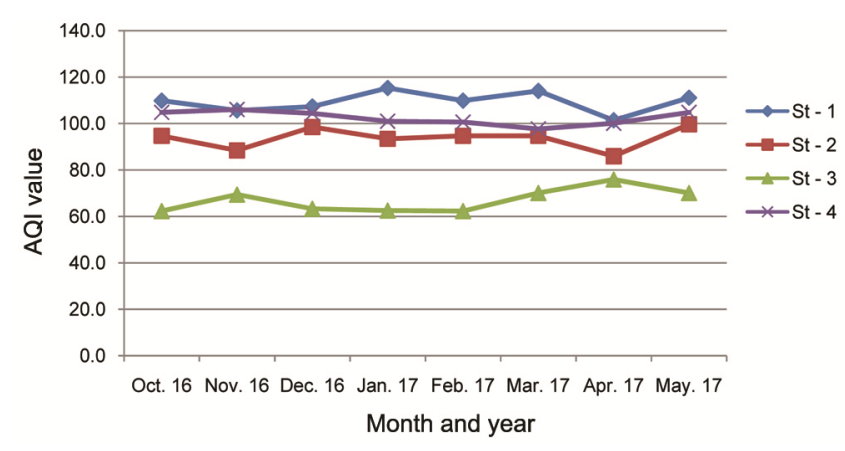

Figure 3. Month-wise graphical representation of air quality index w.r.t different stations.

Table 5. Different air quality index values station-wise

\begin{tabular}{lcccr}
\hline Month and year & ST-1 & ST-2 & ST-3 & ST-4 \\
\hline October 2016 & 109.84 & 94.7 & 62.3 & 104.79 \\
November 2016 & 105.65 & 88.4 & 69.4 & 106.05 \\
December 2016 & 107.31 & 98.5 & 63.3 & 104.39 \\
January 2017 & 115.29 & 93.4 & 62.5 & 101.00 \\
February 2017 & 109.84 & 94.7 & 62.3 & 100.60 \\
March 2017 & 114.02 & 94.7 & 70.1 & 97.68 \\
April 2017 & 101.40 & 85.9 & 75.9 & 100.14 \\
May 2017 & 111.10 & 99.7 & 70.1 & 104.79 \\
\hline
\end{tabular}

permissible limits with respect to $\mathrm{PM}_{10}$ and $\mathrm{PM}_{2.5}$ at two out of four locations, whereas mean value of gaseous pollutants $\mathrm{SO}_{2}$ and $\mathrm{NO}_{x}$ are found below the permissible limits. On the basis of results, two locations were found to be most affected having mean confrontations of $\mathrm{PM}_{10}$ from 101.6 to $122.5 \mu \mathrm{g} / \mathrm{m}^{3}$ and 96 to $108.6 \mu \mathrm{g} / \mathrm{m}^{3}$ and mean confrontations of $\mathrm{PM}_{2.5}$ from 37.7 to $54.8 \mu \mathrm{g} / \mathrm{m}^{3}$ and 30.86 to $49.23 \mu \mathrm{g} / \mathrm{m}^{3}$ at locations 1 and 4 respectively. The mean confrontations of $\mathrm{NO}_{2}$ was from 28.6 to $53 \mu \mathrm{g} / \mathrm{m}^{3}$ and 17.3 to $40.5 \mu \mathrm{g} / \mathrm{m}^{3}$ at locations 1 and 3 respectively. However, $\mathrm{SO}_{2}$ at all four locations was well within the limits and thus negligible. Locations 2 and 3 were found least affected compared to the other two locations with respect to respirable and fine suspended particulate matter, where the mean value of $\mathrm{PM}_{10}$ was 93.4 to $99.7 \mu \mathrm{g} / \mathrm{m}^{3}$ and 62.3 to $75.9 \mu \mathrm{g} / \mathrm{m}^{3}$ and mean value of $\mathrm{PM}_{2.5}$ was 21.1 to $37.2 \mu \mathrm{g} / \mathrm{m}^{3}$ and 17.58 to $40.23 \mu \mathrm{g} / \mathrm{m}^{3}$ respectively. The mean value of $\mathrm{NO}_{2}$ at locations 2 and 3 was found to be 13.1 to $31 \mu \mathrm{g} / \mathrm{m}^{3}$ and 17.3 to $36.3 \mu \mathrm{g} / \mathrm{m}^{3}$ as least affected compared to locations 1 and 4 . According to the CPCB 2014 guidelines, AQI was found to be 115.29 , which is under the category of moderately polluted according to the AQI range (101-200).

1. Rao, C. S., Environmental Pollution Control Engineering, New Age International Publishers, 2006, 2nd edn, pp. 229-239.

2. Singh, S. K. and Rao, D. N., Evaluation of the plants for their tolerance to air pollution. In Proceedings of the Symposium on Air Pollution Control, IIT Delhi, 1983, pp. 218-224; WBWX7geNJAmwb/final_report8.pafretrieve20/09/2007
3. Zainal Alim Mas'ud, S., Nasrullah, N., Bey, A. and Tjitrosemito, S., Tolerance levels of roadside trees to air pollutants based on relative growth rate and air pollution tolerance index. Hay. J. Biosci., 2008, 15(3), 123-129.

4. Agrawal, M. and Singh, J., Impact of coal power plant emission on the foliar elemental concentrations in plants in a low rainfall tropical region. Environ. Monit. Assess., 2000, 60(3), 261-282.

5. Shukla, V. and Dalal, P., Impact of vehicular exhaust an ambient air quality of Rohtak city, India. J. Environ. Biol., 2010, 31, 929932.

6. Lim, J. M., Lee, J. H., Moon, J. H., Chung, Y. S. and Kim, K. H., Source apportionment of $\mathrm{PM}_{10}$ at a small industrial area using positive matrix factorization. Atmos. Res., 2010, 95, 88-100.

7. Dash, S. K. and Dash, A. K., Determination of air quality index status near Bileipada, Joda area of Keonjhar, Odisha, India. Indian J. Sci. Technol., 2015, 8(35), 1-7.

8. Dash, S. K. and Dash, A. K., Assessment of ambient air quality with reference to particulate matter $\left(\mathrm{PM}_{10}\right.$ and $\left.\mathrm{PM}_{2.5}\right)$ and gaseous $\left(\mathrm{SO}_{2}\right.$ and $\left.\mathrm{NO}_{2}\right)$ pollutant near Bileipada, Joda area of Keonjhar, Odisha, India. Pollut. Res., 2015, 34(4), 817-824.

9. Dash, A. K. and Dash, S. K., Atmospheric pollution load assessment through air quality index: a case study. Indian J. Environ. Prot., 2017, 37(9), 736-741.

10. Sahoo, D., Dash, A. K. and Sahu, S. K., Ambient air quality monitoring and health impact study of air pollution near Joda of Keonjhar, Odisha, India. Int. J. Eng. Sci. Res. Technol., 2017, 6(1), 429-434.

11. Kumar, S. D. and Dash, A., Seasonal variation of air quality index and assessment. Global J. Environ. Sci. Manage., 2018, 4(4), 483492.

12. EIPPC, Reference document on best available techniques in the cement and lime manufactory industries, European Integrated Pollution Prevention and Control Bureau, Seville, Spain, 2001.

13. Marland, G., Boden, T. A., Grifin, R. C., Huang, S. F., Kanciruk, P. and Nelson, T. R., Estimates of $\mathrm{CO}_{2}$ emission from fossil fuel burning and cement manufacturing based on the United National Energy Statistics and the US Bureau of Mines Cement Manufactory Data Report N0\# ORNL/DIAL25, Tennessee, USA, 1989.

14. Ruth, M., Worrell, E. and Price, L., Evaluating clean development mechanism project in the cement industry using a process step benchmarking approach. US Department of Energy, 2000.

15. Jeff, G. and Hans, P., Assessment of Environmental Impact of the Holcim Cement - Dundee Plant, Ecology Centre, 2004; http:// www.wbsed.org/web/project/cement/tf5/holcmm.htm (retrieved on 13 October 2007).

16. Barman, S. C., Singh, R., Negi, M. P. S. and Bhargava, S. K., Ambient air quality of Lucknow City, India during use of fireworks on Diwali festival. Environ. Monit. Assess., 2008, 137, 495-504.

17. Dash, A. K., Sahu, S. K., Pradhan, A., Kolli, R. N. and Dash, S. K., Air dispersion model to study the point source air pollution and its impact on ambient air quality. Asian J. Chem., 2017, 29(5), 1150-1154.

18. Kumar, D. S., Bhushan, S. H. and Kishore, D. A., Atmospheric dispersion model to predict the impact of gaseous pollutant in an industrial and mining cluster. Global J. Environ. Sci. Manage, 2018, 4(3), 351-358.

19. Dash, S. K. and Dash, A. K., Atmospheric dispersion modeling by using AERMOD to predict the impact of $\mathrm{PM}_{10}$ near Bileipada, Odisha. Indian J. Env. Prot., 2019, 39(4), 299-306.

20. Banerjee, D. and Pandey, G. S., Micro-pollutant particulates in the ambient air of a cement plant. Int. J. Environ Anal. Chem., 1989, 35, 169-174.

21. Gupta, A. K., Some studies on industrial air pollution in Kymore region and its impacts on plants and human health. $\mathrm{Ph} \mathrm{D}$ thesis, APS University, Rewa, 1994.

22. Chandrasekharan, G. E., Ravichandran, C. and Mohan, C, A., A short report on ambient air quality in the vicinity of a cement plant at Dalmiapuram. Indian J. Environ. Prot., 1998, 18(1), 7-9. 
23. Agrawal, M. and Khanam, N., Variation in concentrations of particulate matter around a cement factory. Indian J. Environ. Health, 1997, 39(2), 97-102.

24. Shrivastava, J., Studies on the air quality status and its impacts on vegetation proximate or cement plant of Sarlanager, Maihar (M.P.). Ph D thesis, A.P.S. University, Rewa, M.P., 1999.

25. Crabbe, H., Beaumont, R. and Norton, D., Assessment of air quality, emissions and management in a local urban environment. Environ. Monit. Assess., 2000, 65(1-2), 435-442.

26. Balaceanu, C. and Stefan, S., The assessment of the TSP particulate matter in the urban ambient air. Rom. Rep. Phys., 2004, 564, 757-768.

27. Pope III, C. A., Epidemiology of fine particulate air pollution and human health: biologic mechanisms and who's at risk? Environ. Health Perspect., 2000, 108, 713-723.

28. HEI, Reanalysis of the Harvard six cities study and the American Cancer Society study of particulate air pollution and mortality. A Special Report of the Health Effects Institute's Reanalysis Project, Health Effects Institute, Cambridge, MA, USA, July 2000.

29. WHO, Guidelines for air quality, WHO/SDE/OEH/00.02. World Health Organization, Geneva, Switzerland, 2000; http://www. who.Int/peh

30. Dash, S. K., Dash, A. K. and Pradhan, A., Statsitical approach to sudy the ambient air quality parameters in Bileipada, Keonjhar, Odisha, India. Int. J. Engg. Techn., 2018, 7(4.39). 627-632.

31. Dash, S. K. and Dash, A. K., Air pollution tolerance index to assess the pollution tolerance level of plant species in industrial areas. Asian J. Chem., 2018, 29(12), 219-222.

32. Boyd, J. T., Climate, air pollution and mortality. Br. J. Prev. Soc. Med., 1960, 14(3), 123-135.

33. Bhuyan, P. K. and Samantray, P., Ambient air quality status in Choudwar area of Cuttack district, India. Int. J. Environ. Sci., 2010, 1(3), 343-356.

34. Chaurasia, S., Karwariya, A. and Gupta, A. D., Air pollution and air quality index of Kodinar Gujarat, India. Int. J. Environ. Sci., 2013, 25, 62-67.

35. Chaulya, S. K., Spatial and temporal variations of SPM, RPM, $\mathrm{SO}_{2}$ and $\mathrm{NO}_{x}$ concentrations in an opencast coal mining area. $J$. Environ. Monit., 2004, 6, 134-142.

36. Dockery, D. W., Schwartz, J. and Spengler, J. D., Air pollution and daily mortality: associations with particulates and acid aerosols. Environ. Res., 1992, 59, 362-373.

37. Ostro, B. D., Lopsett, M. J., Wiener, M. B. and Selner, J. C., Asthmatic response to airborne acid aerosol. Am. J. Public Health, 1991, 81, 694-702.

38. Roemer, W., Hoek, G. and Brunkreef, B., Effect of ambient winter air pollution on respiratory health of children with chronic respiratory symptoms. Am. Rev. Respir. Dis., 1993, 147, 118-124.

39. West, P. W. and Gaeke, G. C., Fixation of sulphur dioxide as sufitomercurate III and subsequent colorimetric determination. Anal. Chem., 1956, 28, 1816-1819.

40. Jacobs, M. B. and Hochheiser, S., Continuous sampling and ultra micro determination of nitrogen dioxide in air. Anal. Chem., 1958, 30, $426-428$.

Received 5 February 2019; accepted 28 February 2019

doi: $10.18520 / \mathrm{cs} / \mathrm{v} 116 / \mathrm{i} 11 / 1905-1909$

\section{Comparison between Scopus, Web of Science, PubMed and publishers for mislabelled review papers}

\author{
Andy Wai Kan Yeung* \\ Oral and Maxillofacial Radiology, Applied Oral Sciences, \\ Faculty of Dentistry, The University of Hong Kong, Hong Kong, China
}

The present study examined the incidence rate of reviews being mislabelled by Scopus, and compared this rate with Web of Science (WoS), PubMed and official websites of publishers. Top 400 cited publications defined by Scopus as 'articles' were examined. Their contents were evaluated to see if any were actually reviews. These publications were cross-checked in WoS, PubMed and publisher websites to identify the assigned document type labels. Out of the 400 Scopus 'articles', 117 were reviews $(\mathbf{2 9 . 3 \% )})$. The official websites of publishers had $16.0 \%$ incidence of mislabelled reviews, which was less than Scopus $(29.3 \%)$ but more than WoS (14.1\%) and PubMed (1.9\%).

Keywords: Document types, library science, information science, periodical articles, reviews.

Multiple databases such as Scopus, Web of Science (WoS) and PubMed index biomedical publications. The data and meta-data associated with the publications are useful for library science and bibliometric evaluations such as citation analyses. Each database has its own advantages and shortcomings; for instance, PubMed can be accessed for free, whereas Scopus and WoS track the citation count of the publications ${ }^{1}$. It is intuitive to recognize that each database has a different collection of literature tracked/indexed and possesses different features that provide different results for citation analyses. For example, it has been reported that Scopus covers a broader biomedical literature particularly the non-Englishlanguage sources ${ }^{1,2}$ but WoS tracks older citations better ${ }^{3}$. Meanwhile, another study has concluded that WoS classifies journals more accurately than Scopus ${ }^{4}$. More recent studies have pointed out that there are discrepancies and inaccuracies in the funding and affiliation information indexed by Scopus, WoS and PubMed ${ }^{5,6}$. One important aspect that is yet to reach a consensus is the accuracy of document type label, known as 'document type' in Scopus and WoS and 'publication type' in PubMed. For instance, a recent survey by Donner ${ }^{7}$ reported $17 \%$ document mislabelling by WoS, and $24 \%$ by Scopus ${ }^{7}$. Besides, the differences in document type labelling by WoS and Scopus have caused up to $50 \%$ discrepancy in original article count in various pharmacology journals when the two databases were compared - though the exact ratio of mislabelling has not been reported ${ }^{8}$. Another

*e-mail: ndyeung@hku.hk 